\title{
Cabo Verde: entre uma civilização agrícola e uma civilização industrial e comercial
}

(1822-1841)

\author{
Eduardo Adilson Camilo Pereira ${ }^{1}$
}

Resumo: O presente artigo pretende analisar os diversos discursos políticos produzidos e reproduzidos pelas elites políticas em Cabo Verde, em torno de qual ilha deveria sediar a capital do arquipélago. Pretende ainda demostrar a atualidade desse discurso na mobilização política das ilhas de Santo Antão, São Vicente e São Nicolau contra a centralidade político-administrativa da vila da Praia, assente na criação de uma civilização industrial e comercial em Mindelo, em torno da navegação.

Propõe ainda analisar e compreender os argumentos político-económicos apresentados para justificar a transferência do governo, como especial atenção para a centralidade geográfica, comércio externo e existência de bom porto para a navegação.

Palavras-chave: Cabo Verde; mobilização política; civilização; elites políticas;

\begin{abstract}
This article aims to analyze the different political discourses produced and reproduced by the political elites in Cape Verde, around which island would host the capital of the archipelago. It also aims to demonstrate the relevance of this discourse in the political mobilization of the islands of Santo Antao, Sao Vicente and Sao Nicolau against political and administrative centrality of the village of Praia, based on the creation of an industrial and commercial civilization in Mindelo, around the navigation.

It also proposes to analyze and understand the political and economic arguments to justify the transfer of the government, as a special attention to the geographical centrality, foreign trade and the existence of safe harbor for shipping.
\end{abstract}

Keywords: Cape Verde; political mobilization; civilization; political elites;

1 Doutor em História pela Universidade de São Paulo (USP). É professor Doutor no Departamento de Ciências Sociais e Humanas da Universidade de Cabo Verde (Uni-CV), onde tem participado da coordenação do Programa de Mobilidade entre a UFMG e a Uni-CV. Também é professor regente no Instituto Superior de Ciências Jurídicas e Sociais. Atualmente é candidato a pós-Doutorado. E-mail: eduardo.pereira@docente.unicv.edu.cv 


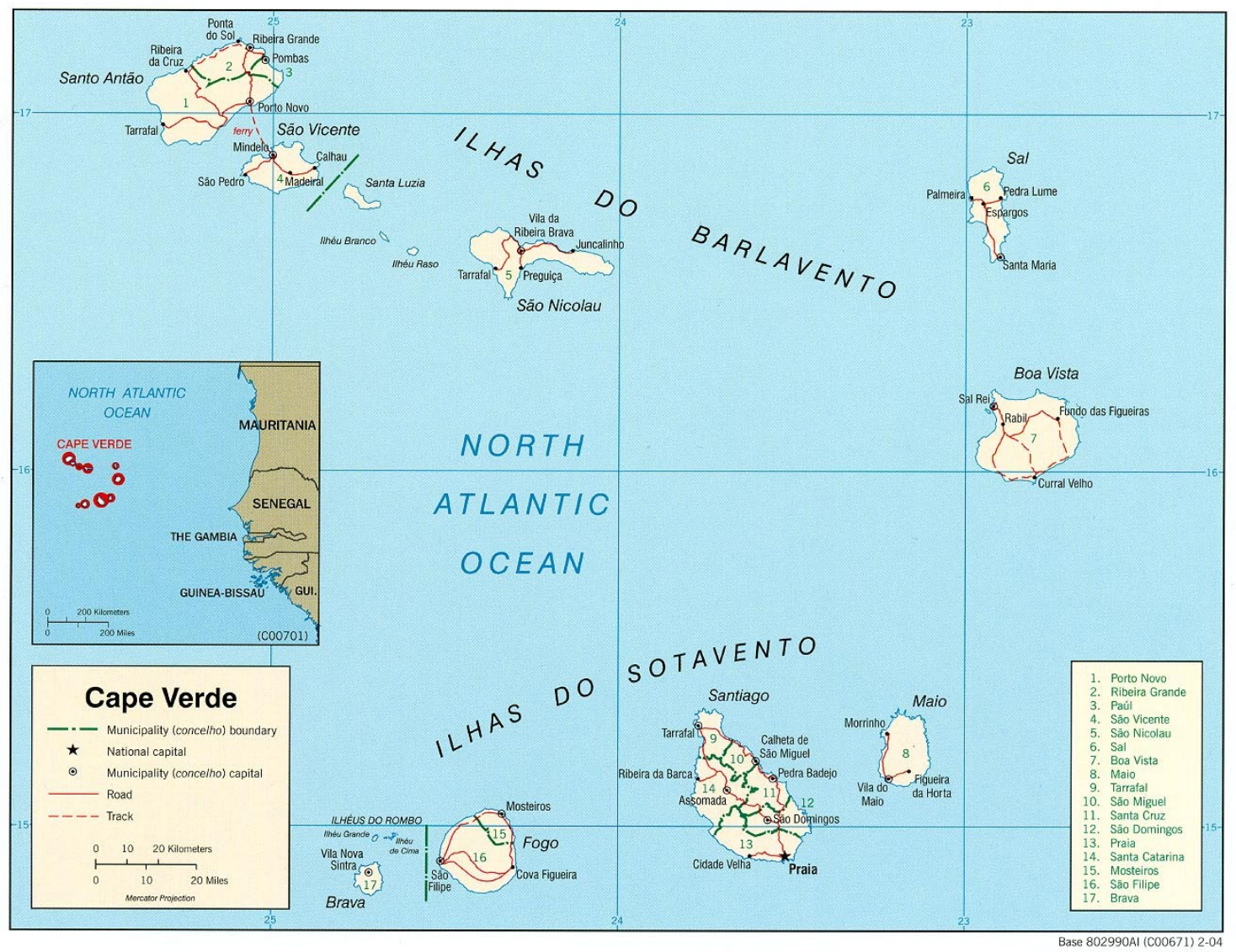

Mapa 1. Localização das ilhas de Cabo Verde.

Cabo Verde é hoje um país formado por dez ilhas, sendo nove habitadas. Poderíamos questionar: por quê é uma integração das dez ilhas e não uma separação? Em volta desta pergunta, desde os primórdios do povoamento das ilha de Santiago e do Fogo, foram produzidos e reproduzidos, pelas elites políticas locais, diversos discursos políticos em torno da ilha que deveria sedear a capital do arquipélago.

José Conrado Carlos de Chelmicki foi o primeiro estudioso a questionar as reais motivações que levaram as elites políticas locais a proporem a transferência da sede do governo da ilha de Santiago para as demais ilhas. Segundo este, a formação de povoações propiciava não só o aumento da produção, como também a divulgação dos valores da agricultura "provincial". Destaca ainda que o caráter litorâneo das primeiras povoações, centradas na vila da Praia e na Ribeira Grande, atrasou muito os planos do governo colonial para a criação de povoações agrícolas no interior. A vila da Praia era a única vila existente na ilha de Santiago, sendo, por isso, imprescindível a criação de uma nova vila num local onde o clima era mais agradável. O local mais adequado seria a achada de 
Santa Catarina (atual cidade de Assomada), onde o clima, segundo este, era mais saudável.

(...) O sitio mais conveniente é a achada de Santa Catharina. N'uma planice reputada por mui saudavel, abundante d'agua e rica em vegetação, no centro da ilha, não tardaria de se formar em breve uma povoação, uma Villa agradável. Grandes porções de terreno ainda incultas daríamos a agricultura e por este meio conseguiríamos o nosso fim (....). ${ }^{2}$

Para este naturalista português, a falada insalubridade climática da Ribeira Grande, sem fundamento, pintada com cores negras em Portugal, causava grande prejuízo a administração da colônia, tendo em vista que os portugueses partiam de Portugal com uma idéia pré-estabelecida acerca da cidade, vista como uma sepultura dos europeus. A tão proclamada insalubridade da Ribeira Grande prejudicou a administração da cidade. As informações que circulavam na Corte sobre o seu clima provocou muitos receios naqueles que para lá eram mandadas. Para este autor, as tão faladas carneiradas, que dizimavam tripulações inteiras na costa africana, eram fantasmagóricas. ${ }^{3}$

Entretanto, não deixa de reconhecer que a retirada das principais autoridades da ilha de Santiago, onde está localizada a sede do governo colonial, em certos meses do ano, fugindo das “doenças da terra”, vinha acarretando grande prejuízo à administração pública da província de Cabo Verde. Segundo este, a ilha de São Vicente, por gozar não só de melhor clima, como também de um bom porto, merecia ser a sede do governo colonial. ${ }^{4}$

Por seu turno, Christianno José Senna Barcellos, ao escrever sobre as mobilizações políticas em Cabo Verde, baseou-se sobretudo nas recolhas em arquivos portugueses dos ofícios e relatórios dirigidos à coroa pelos antigos governadores. Em seus Subsídios para a História de Cabo Verde e Guiné, procura destacar a importância das idéias liberais, principalmente a de libertar a terra e o próprio contexto da independência do Brasil, como condicionantes da "desordem" registrada nos dois morgadios do interior da Ilha de Santiago. Barcellos inclusive chama a atenção para o projeto de constituição de um partido pró-Brasil, tendo como objetivo unir as ilhas de Cabo Verde ao Brasil. Para o referido estudioso, seriam sobretudo os degredados com seus "maus exemplos" os propagadores de idéias liberais que acabaram por ter um papel fundamental na eclosão desses

2 CHELMICKI, José Conrado Carlos de. Corografia Cabo-verdiana ou descripção geographico-historico da Província das Ilhas de Cabo-Verde e Guiné. Lisboa: Typ. de L. C. da Cunha, 1841, t.I, p. 199-200.

3 Idem, p. 296.

4 Id., Ibid., t. II, p. 129-130. 
movimentos. ${ }^{5}$

Entretanto, em nenhum momento, essas mobilizações políticas foram analisadas nas suas especificidades, como sinais de descontentamento de alguns setores da sociedade caboverdiana. Por outro lado, Barcellos não articulou a constituição do partido pró-Brasil ao projeto de criação de uma civilização ocidental na ilha de São Vicente e nem, muito menos, analisou as estratégias políticas empregues para mobilizar os seus habitantes.

Por outro lado, procura destacar tanto a insalubridade do clima, como também a precariedade do porto que cerca a cidade da Ribeira Grande. Além do mais, salienta uma exposição feita pela câmara da Praia, dirigida à Rainha, pela qual propunha a fundação de uma povoação agrícola no interior da ilha de Santiago e, consequentemente, a construção de uma rede de estradas para facilitar o escoamento dos produtos agrícolas. ${ }^{6}$

Por seu turno, Henrique Galvão e Carlos Selvagem em seu Império Ultramarino português ${ }^{7}$, da mesma forma que Barcellos, ao analisar as mobilizações políticas dão ênfase ao projeto separatista do arquipélago em relação a Portugal, bem como ao plano da constituição de uma "Confederação Brasílica", abrangendo Brasil, Cabo Verde, Angola e Moçambique. Porém, os referidos estudiosos não articularam o projeto emancipacionista às mobilizações no campo, nem tão pouco demonstraram como essas idéias partidárias foram ressignificadas na prática das revoltas políticas.

Quanto ao Brigadeiro R. J. da Cunha, defende que os padres não só desejavam a transferência da sede do governo, devido a intempérie do clima da Ribeira Grande, como também pelo conhecimento de "que as ilhas do Cabo Verde tinham dado quanto podiam dar, e agora estavam reduzidos a um cadáver mirrado". ${ }^{8}$

Já para Ilídio do Amaral, “(...) o Governo passava de ilha para ilha, a pretexto da

5 BARCELLOS, Christianno José Senna. Subsídios para a História de Cabo Verde e Guiné. Lisboa, 1899-1911, parte IV, v. I, p. 279.

6 Id., Ibid., parte V, 136, p. 215-221.

7 GALVÃO, Henrique e SELVAGEM, Carlos. Império Ultramarino português. Lisboa: Imprensa Nacional de Publicidade, 1951, v. I, p. 53; p. 99; p. 186.

8 MATOS, Brigadeiro R. J. da Cunha. Compêndio histórico das possessões de Portugal na África. Rio de Janeiro: Ministério da Justiça e Negócios Interiores - Arquivo Nacional, 1963, p. 47-49. 
insalubridade de Santiago, com grande aumento de despesas e fortes prejuízos. (...)". 9 Segundo este, a manutenção da sede do governo colonial português na vila da Praia implicaria na mudança constante dos membros do governo "de ilha para ilha", fugindo da insalubridade do clima. Neste sentido, destaca as tentativas fracassadas da Coroa portuguesa na mudança da sede do governo para a ilha de São Vicente, em 1844 e 1850. Além disso, regista outras propostas que indicavam o interior da ilha de Santiago não só como melhor opção para a instalação da sede do governo, como também para promover o desenvolvimento da agricultura ali praticada.

Quanto aos estudos mais recentes, vale ressaltar a de António Carreira. Em seu "Cabo Verde (Aspectos Sociais. Secas e fomes do século XX)", registrou o fato da insalubridade da Ribeira Grande ter impossibilitado a plena organização do ensino, tendo em vista que os padres não sabiam onde construir o colégio. ${ }^{10}$ À semelhança de Barcellos, Carreira também destaca a influência das idéias liberais propagadas pelo número de degredados radicados nas ilhas de Cabo Verde.

Quanto aos estudos mais recentes, cabe destacar o de Elisa Silva Andrade em "As Ilhas de Cabo Verde: da Descoberta à Independência Nacional (1460-1975), Cap. IV "Declínio e Fim da Sociedade Escravista", discute o declínio da sociedade escravista como elemento condicionante das revoltas políticas. Para esta renomada historiadora cabo-verdiana, a deteoração da situação económica, financeira e social de Cabo Verde, na primeira metade do século XIX, bem como a submissão a condições de vida desumanas, foram determinantes para a eclosão das revoltas políticas. $^{11}$

É possível afirmar que as duas propostas feitas pela Junta administrativa de Cabo Verde, em 1803 e 1819, respectivamente, para a transferência da sede do governo colonial, ao contrário das propostas anteriores, que inclinava, na maioria dos casos, para a vila da Praia, defendiam a escolha de outras ilhas, como sejam: Fogo, Santo Antão, São Nicolau e São Vicente. É possível verificar nestas duas propostas outras motivações que não sejam de cunho meramente climática, para além de abarcar em sua proposta outras ilhas que nunca fora cogitada. Em nenhum momento as diversas

9 AMARAL, Ilídio do, Santiago de Cabo Verde: A Terra e os Homens. Lisboa: Memórias da Junta de Investigação do Ultramar, n. 18, 1964, p. 185.

10 CARREIRA, António. Cabo Verde (Aspectos Sociais. Secas e fomes do século XX). $2^{\mathrm{a}}$ ed., Lisboa: Ulmeiro, 1984 (1977), p. 141; p. 149.

11 ANDRADE, Elisa Silva. As Ilhas de Cabo Verde: da Descoberta à Independência Nacional (1460-1975). Paris: Éditions L'Harmattan, 1996, p. 115. 
propostas foram analisadas, tendo em vista o panorama cultural da ilha de Santiago, identificado na resistência que os habitantes do interior faziam às autoridades administrativas. A historiografia procura destacar a adversidade climática da ilha de Santiago, sem indagar sobre a disputa de poder, registrada entre os membros do governo local, em prol das diversas ilhas que compõem o arquipélago de Cabo Verde.

A primeira notícia que se tem registro dos arquivos europeus acerca da tentativa da transferência da sede do governo colonial português no arquipélago de Cabo Verde data de 1582. Diego Florez de Valdez, numa Carta ao Rei D. Filipe I, de 24 de janeiro de 1582, propôs a Coroa a transferência do trato para a vila da Praia, onde o porto, além de dispor de uma boa baía, também destacava pelo seu tamanho. Além disso, era também passagem obrigatória para a navegação da costa da Guiné, São Tomé e Brasil. Por outro lado, além de destacar a importância da ilha de Santiago para a Sua Magestade e sua Real Fazenda, este viajante, registrou o fato da vila da Praia ser mais sadio (sano) do que a Ribeira Grande, onde até o momento vinha sendo a sede do governo colonial. $^{12}$

A mesma opinião repete-se na Carta de 12 de julho de $1586 .{ }^{13}$ Nesta, o padre Baltazar Barreira, responsável máximo pela missão jesuítica de evangelização na costa ocidental africana, defendeu a mudança imediata da sede do governo colonial para a vila da Praia, mesmo contra a vontade dos moradores (vizinhos) da Ribeira Grande. Segundo o mesmo, para além da vila dispor de um bom porto, era mais sadia, tendo em vista que estava localizada num planalto, cercada por duas ribeiras. Porém, não deixou de realçar o risco de ataques piratas, uma vez que a vila da Praia encontrava-se despovoada, o que dificultava muito a sua defesa. ${ }^{14}$ A própria instalação do Seminário e da Casa professa dos Jesuítas em Cabo Verde, idéia há muito acalentada pela Coroa, ficou comprometida diante da insalubridade, com "perda da Religião", uma vez que os padres, diante do clima agreste, sentiam-se impossibilitados de cumprir o serviço de Deus "que é o santo fim que Sua Magestade pretéde, e sem alcançar o fruito desejado". ${ }^{15}$

12 VALLE, Marqués de la Fuentesanta del; RAYON, D. José Sancho; ZABÁLBURU, D. Francisco de. Coleccion de documentos inéditos para la historia de Espanã. Madrid, 1889, t. XCIV, p. 540-544.

13 AGS, Secretarias Provinciales (Portugal), liv. 1550, fl. 357-357 v.

14 AV, Processus Consistorialis, v. II, fl. 310, de 31 de Março de 1608. Ver ainda: ANTT, Cartório dos Jesuítas, maço 36, doc. 94, fls. 4, de 12 de fevereiro de 1609. ANTT, Cartório dos Jesuítas, maço 36, doc. 92, de 9 de maio de 1609.

15 ARSI, Lus., cód. 83, fls. 353 v. - 354 v., de março de 1608. 
Assim, por meio do Alvará Régio de 14 de Agosto de 1612, el Rei determinou, sem sucesso, que tanto o governador quanto o bispo passassem a residir na vila da Praia, tendo como objetivo a reedificação das casas. O despacho do algodão e frutos para a Guiné teria, a partir daquele momento, de ser feito exclusivamente pelo porto da vila da Praia. Estabelece ainda dois anos de degredo para a ilha do Fogo e vinte cruzados em dinheiro para os desobedientes. Como incentivos, o Rei passou a conceder duas liberdades àqueles que levantassem suas casas de pedra e cal, cobertas de telha, na referida vila, traduzidas no desconto em cada peça de escravo ( 2 mil reis) por um período de cinco anos. A Coroa comprometeu-se ainda com a canalização da água potável para a vila da Praia. ${ }^{16}$

Por sua vez, o padre Fernão Guerreiro, além de destacar o clima sadio da vila da Praia, o seu notável porto e a baía que o cerca, não obstante a existência de poucas casas, defendeu a fortificação e povoamento da vila para defesa contra as incursões piratas. Para este, de nada adiantaram as várias tentativas feitas pela Coroa portuguesa para mudar a sede do governo para a vila da Praia. Haveria, segundo este padre, melhores condições defensivas da vila da Praia em relação a Ribeira Grande, tendo em vista que em frente da baía existia um ilhéu. Porém, isso só seria conseguido com a presença não só de pessoas para vigiar a vila, como também para a defender em caso de ataque corsário. Assim:

(...) Muytas vezes se tratou de mudarem a cidade para este sitio, o que se tivera effeyto, fora grande bem, porque nem se perderam os navios, que continuadamente se perdem no porto della, nem a doeçera, nem morrera tanta gente (...). ${ }^{17}$

Marcelino António Bastos, governador de Cabo Verde entre 1796 e 1808, por meio de uma proposta enviada a Lisboa, propôs para a transferência da sede do governo para a ilha do Fogo, com base na produção agrícola de todas as ilhas do arquipélago de Cabo Verde, no acesso à agua potável e existência de um bom porto para a navegação. Segundo este,

(...) estabelecida a Capital na Ilha do Fogo se conhece a grande utilidade que desta mudança resultaria a bem do Estado, das Ilhas, ou seus Habitantes, porque nella em razão do seu benigno Clima mui estão sujeitos

16 AHU, Cabo Verde, Cx. 1/doc. n. 15.

17 GUERREIRO, Padre Fernam. Relaçam Anual das Cousas que Fezeram os Padres da Companhia de Jesus nas partes da Índia Oriental, e no Brasil, Angola, Cabo Verde, nos annos de seiscentos e dous e seiscentos e três, e do processo de conversam, e christandade daquellas partes, tirada das cartas dos mesmos padres que de lá vieram. Lisboa: Per Jorge Rodriguez, 1695 (1605), p. 130-131. 
os Europeos á doença do Paiz como na de Sant'Iago, e maio, e só as que os homens estão sujeitos como descendentes de Adão (...)a Ilha hé, povoada há mais de 2 séculos, e que sempre na villa habitarão moradores, e qo aumento de 1 ou 2 duzia de pessoas mais não farão a agoa mais escassa.Tambem na villa da Praya em St Iago quem nella bahita, e quer beber agoa boa a manda buscar de distancia de perto de legoa (...)também tem a vantagem de poderem estar os navios na Ilha do Fogo em todo e qualqr. tempo ou estação, o q. não pode sêr na de Sant'Iago sem manifesto risco de Agosto até Outubro. ${ }^{18}$

Para dar cumprimento à determinação da Coroa portuguesa, o qual mandou "examinar qual destas Ilhas das cituadas ao Norte, sera a mais própria para se plátar a Sede do governo, e mudar da Ilha de São Thiago para ella, a Capital desta Colonia", ${ }^{19}$ o secretário da Junta da Fazenda, Joaquim Jozé de Araujo apresentou três ilhas: Santo Antão, São Vicente e São Nicolau. O relatório deveria analisar três aspectos fundamentais. Primeiro, analisar as consequências econômicas da transferência da sede do governo da ilha de Santiago. Segundo, deveria selecionar qual delas era mais apropriada para sedear a nova capital. Terceiro, os meios financeiros necessários para a construção de novos edifícios públicos.

A Junta da Fazenda também discordava da centralidade da ilha de Santiago, chegando mesmo a reiterar que "vantajoza posição geográfica, que erradamente tem inculcado alguns q. sobre estas Ilhas tem lançado vistas económicas para motivarem a conveniência, ou necessidade de ser a Ilha de São Thiago a Sede deste Governo". Para esta, os rendimentos financeiros das ilhas do Fogo, da Brava, de Santo Antão e de São Nicolau ultrapassava os da ilha de Santiago. Pelo fato da vila da Praia ser a sede do governo, obrigava todos os navios a frequentarem o seu porto. Reiterou ainda que o comércio ali praticado resumia-se a "objectos de refresco" destinado a abastecer os navios que por ali passavam.

Por outro lado, a transferência da sede do governo da ilha de Santiago para as demais ilhas do arquipélago implicaria a transferência de todos os impostos pagos, sobretudo pelos funcionários públicos. Tal iniciativa política era justificada pela intempérie da ilha de Santiago, ao ponto de levar a Junta a reiterar que -

(...) onde a humanidade não seja sujeita a prova de huma moléstia [doença] tão terrivel como aqui na ilha de São Thiago padecem todos os que não são climatizados, e de que muitos são victimas, e alguns anos de tal

18 AHU, Cabo Verde, Cx. 54, doc. 54, de 10 de Outubro de 1803.

19 AHU, Cabo Verde, Cx. 66, doc. 30, de 27 de Março de 1819. 
caracter, que não respeita os proprios indígenas (...) não obstante a tão gabada fertilidade, e vantajosa posição huma vez que os que nella residem necessariamente hão de sofrer a moléstia, que em toda a Costa d'Africa se chama Carneiradas, e que qualquer das trez propostas Ilhas não tem (...) a Ilha de São Thiago, era hum matadouro dos Europeos, e os empregados que para aqui vinhão erão victimas da morte, por aquella molestia, que Outrora o Senhor Dom Jozé Primeiro de Sandoza Memoria, se propóx mudar a Sede deste Governo para huma das suas Ilhas saudaveis, como fez em São Thomé (...). ${ }^{20}$

Para aquela Junta, enquanto a capital do arquipélago permanecer na ilha de Santiago, os funcionários públicos enviados de Lisboa jamais esforçavam para "preencher bem os deveres dos seus ministérios". Pelo contrário, "os primeiros empregados não procurão se não tratar da própria conservação". A mudança da capital possibilitaria não só que os mesmos desempenhassem, com zelo, as suas atribuições, como também a própria moralização dos cargos públicos, uma que a maioria era ocupada por degredados. Questiona ainda - "poderá isto conseguir-se, quando hoje só não foge da Capital quem não tem motivo com que pretextar a sua auzencia?’. Segundo este, existia na vila da Praia "huma indicente Rezidencia do Governo feita de Madeira" em ruína, sendo necessário a construção de todos os demais edifícios do governo. $\mathrm{O}$ cabido da diocese da ilha de Santiago não correspondia "aos fins de semelhante Instituição não só pela ignorancia, e inhabilidade dos seus membros, como por estarem em huma Dioceze dezerta, e reduzida a seis indivíduos...”.

Este discurso oficial, para além de destacar os benefícios para os funcionários públicos, também ressalta ser um passo gigante "para se conseguir o melhoramento de todos os ramos da Administração Publica, e por isso tambem o mais conducente para a felicidade em Geral desta Capitania a transladação da sua Capital para huma outra das que são saudáveis”. Segundo esta fala, a ilha de Santiago era vista como uma ilha doentia, formada por rebeldes e reduto de infelicidade. Para tal, apresentou as ilhas de São Nicolau e São Vicente como alternativas à ilha de Santiago.

Quanto ao primeiro, destacou o fato da ilha ser povoada, possibilitando a criação de uma nova cidade na localidade de "Caleijão". Ressaltou o fato da ilha ser povoada por "Artífices, e Obreiros”, o que facilitaria a construção dos novos edifícios públicos necessários para a nova capital do arquipélago. A defesa da nova cidade também seria falicitada. Porém, destacou o fato do porto ser distante e

não seja capaz de receber muitos Navios de Linha entre tanto parece que

20 Idem. 
isto não deve entrar em linha de conta para a escolha da sede de hum Governo, por que em tal cazo, nas Ilhas do Assores a Capital deveria ser em São Miguel, ou Fayal por que bem melhores Portos, e mais Commercio, e não a Ilha Terceira; mas procurou-se talvez a Ilha mais central, e hé o que tambem sucede à Ilha de São Nicolau (...). ${ }^{21}$

Quanto à segunda proposta, realçou que, pelo fato da ilha ser povoada por "cento e tanto habitantes", acarretava maiores despesas financeiras para fundar uma nova capital na ilha de São Vicente, "por que para huma terra quazi despovoada tudo hé necessário conduzir-se de fora". Porém, destacou o fato da ilha não ter uma "Ribeira de agua perene, e ainda que se certifique, que nella á duas braças de profundidade em qualquer parte se acha agoa...como um artigo de primeira necessidade hé preciso hum ...atento exame antes que se se emprehenda operação alguma...". Como contrapartida, foram apresentados dois argumentos: a fertilidade do seu solo e a “excellencia" do seu porto, considerado o melhor de todas as demais ilhas do arquipélago.

As intrigas políticas e as reivindicações pela reforma da constituição seriam reforçadas pelas reivindicações políticas locais, dentre as quais, que o governo geral deveria estar sediado nas demais ilhas do barlavento. Para esta discussão muito contribuiu o receio da elite local quanto a um possível ataque dos habitantes do interior da ilha de Santiago, representados como sendo revoltosos e rebeldes. Com as sucessivas revoltas contra o governo geral mobilizadas pelos liberais exaltados, os moderados proporam a construção de um centro civilizacional em Cabo Verde, o que passava necessariamente pela mudança da sede do governo geral para a ilha de São Vicente. Já os exaltados defendiam a manutenção da sede na vila da Praia (ilha de Santiago). Em primeiro lugar, para o deputado da provincia, Theophilo José Dias, liberal moderado, o bem estar de Cabo Verde só poderia ser alacançada com a transferência da capital para a ilha de São Vicente. Para este, a ilha de Santiago não era a ilha mais opulenta do arquipélago. Por isso, não era a "única que mereça $a$ honra de ser a Capital da mesma Provincia". A ilha de Santiago e sua respectiva elite política eram vistos como responsáveis pela decadência econômica das demais ilhas. Além disso, para este governante, a ilha de São Vicente teria melhor localização geográfica para a navegação, além da existência de um excelente porto. Referindo-se ainda a posição geográfica, defendeu que "se $a$ centralidade falta à ilha de $S$. Vicente em relação a todo o archiplago, ella tem a centralidade necessaria respectivamente ao grupo das Ilhas de Barlavento, igualmente rico, importante, e o que infelizmente se acha desprezado". Destacou ainda que tanto o litoral quanto o interior da ilha de Santiago apresentavam um clima insalubre.

21 Idem. 
Em segundo lugar, fazia crer que a "Câmara e Cidadãos signatarios" defendiam que uma das principais prioridades políticas do arquipélago referia-se à "fixação definitiva e permanente da Sede do Governo", tendo em vista a falta de "estabilidade", oriunda das exorbitantes despesas financeiras decorrentes das sucessivas transferências periódicas da sede do governo geral. Estas despesas faziam com que os funcionários recebessem os respectivos salários em até seis meses atrasados, em prejuízo dos serviços da administração do governo geral. Este governante defendia que se tratava de um "egoismo imperdoavel" da câmara da vila da Praia manter a capital do arquipélago na ilha de Santiago que, em tempo das chuvas, era transferido para o interior da ilha. A transferência da sede do governo para São Vicente foi justificada por boa parte da elite política local devido, em parte, ao receio que negros do interior da ilha de Santiago planejassem uma invasão da vila da Praia, para depôr o governador geral nomeado pela Coroa portuguesa.

Porém, destacou a necessidade defendida pela elite política local quanto a criação de "uma povoação no seu centro, e em sitio sádio e que hade ser a necessaria e prompta consequencia de se fixar lá a sede do Governo durante os mezes doentios na Villa da Praia", representadas pelas localidades dos Picos e Orgãos. Questionou a prioridade na criação de uma povoação no centro da ilha de Santiago. Além da grande distância que o separa da vila da Praia, as grandes despesas com o transporte dos serviços, a inacessibilidade ao interior da ilha no periodo chuvoso (junho a outubro), que sempre dificultou o transporte dos "artigos de primeira necessidade" para a vila da Praia, seria uma "desgraça" decretar a sede do governo nos Picos, pois o governo não poderia demandar sobre assuntos que exigiam decisões rápidas. Também destacou que para tal seriam precisos mobilizar avultados recursos financeiros, além do total isolamento da referida localidade em relação à vila da Praia.

Quanto às vias de acesso, notou que "considerem bem (...) o transito de mais de dez leguas, por caminhos completamente escabrados, sujeitos ao ardentissimo sol quando marchassem de diaá perigoza cacimba quando andassem de noite”. Em parte, para este governador, tornava-se "absurdo" fixar a residência do governo no interior da ilha de Santiago, tendo em vista os avultados recursos financeiros necessários para a construção e manutenção de uma estrada que a ligasse à vila da Praia. Em contrapartida, defendeu o investimento deste capital financeiro na edificação de "habitações para o Governo, Bispo e Repartições publicas" numa outra ilha do arquipélago, no caso em Mindelo. Pode-se constatar que a fundação da nova cidade esteva diretamente ligada a crença de que os rendeiros do interior de Santiago não eram capazes de auto-governar-se. 
Em terceiro lugar, refutou o princípio, segundo o qual "todos os habitantes de qualquer Capital, argumentando que só elles, por esse facto, são os mais ricos, mais nobres, e os mais illustrados do resto de seus irmãos do Reino ou Província". Segundo este, todos os relatórios apontavam a existência generalizada das febres quer no litoral, quer no interior da ilha de Santiago, com drásticas consequências para a saúde humana. Para rebater os argumentos quanto à extensão da ilha de Santiago, Marinho reiterou que:

(...) É na verdade extensa; mas pretender que ella só vale o resto da Provincia, é avançar uma enexactidão, um absurso. E quando isto fosse verdadeiro, seria por ventura humano, de rasão e justiça - que as demais Ilhas (oito) não merecessem contemplação egual (...) quem assim fala não tem conhecimento do tamanho da ilha de Sto. Antão, que é tão grande como a de S. Thiago; - e tambem o não há da ilha de S. Nicolau, que, ainda que menor, não deixa de ser extensa (...).

Por outro lado, o mesmo contesta o argumento utilizado pela câmara da vila da Praia, segundo o qual a ilha de Santiago tinha maior número de população do arquipélago. Segundo esta interpretação, os habitantes da provincia não se limitavam aos habitantes da ilha de Santiago. As estatísticas apontavam pouca diferença populacional entre as ilhas de Santiago e Santo Antão.

Em quarto lugar, apesar de admitir que na ilha de Santiago faz-se mais comércio com o exterior, Marinho questiona o "direito de querer tudo para si e nada para as outras, que por não serem tão commerciais e industriosos, por isso mesmo teem mais direito a serem protegidas?". A Coroa portuguesa deveria beneficiar as ilhas que mais necessitam para se desenvolver, ao invés de construir a sede do governo no interior da ilha de Santiago. Ainda não se justificava o argumento da grande distância entre São Vicente e a vila da Praia, tendo em vista que os Picos distava 100 a 150 passos do mar. Segundo este, o investimento para a construção da capital no interior da ilha de Santiago seria quatro vezes superior ao que se poderia despender para a construção de edifícios públicos em Mindello. O governo geral gastaria elevada soma em dinheiro, tendo em vista às péssimas vias de comunicação para o interior da ilha de Santiago e o custo da mão de obra, que era $50 \%$ acima do preço praticado nas ilhas do barlavento. Por isso, "Só quem não conhece os caminhos para o interior de S. Thiago, e ignora quanto custam alli os transportes, é que pode ficar em silencio vendo semelhante proposta:-de ser o seu interior o local da residencia do Governo no tempo das aguas". Para ele, a transferência da capital para a ilha de São Vicente não comprometeria o comércio, a agricultura, a navegação e a importância política da ilha de Santiago. 
Em quinto lugar, Dias contestou o argumento apresentado pelas câmaras da vila da Praia e de Santa Catarina, segundo o qual só a ilha de Santiago exportava café, purgueira e açucar para Lisboa. As ilhas do Fogo e de Santo Antão seriam também responsáveis pela boa parte das safras da purgueira e do café respectivamente. Fazia crer que o trabalho de vários agricultores havia demonstrado que as terras da ilha de São Vicente, considerada em tempos como "improdutiva", eram sobremaneira férteis. Para esta autoridade, ao contrário dos argumentos apresentados pelas elites políticas da ilha de Santiago, a ilha de São Vicente despunha de várias nascentes de água potável para abastecer a futura cidade de Mindello.

Considerou igualmente absurdo o argumento que, com a transferência da capital para outra ilha, diminuiria a confiança no governo que "longe de promover os mananciaes de prosperidade que incerra em si, lhe faça sair o numerario para ir distribuil-o com os Empregados publicos, residindo n'outra parte". Contrapondo aos argumentos apresentados pela câmara da vila da Praia, reiterou ser falso que só a ilha de Santiago contribuía para as despesas do arquipélago, tendo em vista a inatividade dos seus empregados. Entende ainda que a Coroa devesse descentralizar o comércio e a indústria para as outras ilhas do arquipélago, construir boas estradas não só na ilha de Santiago, como também nas ilhas de Santo Antão e São Nicolau, pondo fim ao "estado de ambulância em que há annos andam as Repartições publicas, e o mesmo Governo; o que deve quanto antes cessar". Segundo este,

Que a fixação da Sede do Governo n'aquella Ilha seja a única medida que de prompto lhe pode dar um impulso de prosperidade porque a Ilha não tem precisado de tal medida para prosperar como tem prosperado - porqe. Ella só por si se hade illustrar, e civilizar como affirmam os representantes; - e a Provincia não há de florescer por estar o Governo na Ilha de S. Thiago; Pelo contrario, se alli se estabelecessem as Escolas Publicas, ninguem as frequentaria (...) nem os Empregados das duas Repartições superiores Secretaria, e Contadoria - estarião em estado de poder desempenhar suas respectivas obrigações, por falta de saude.

Em sexto lugar, para o referido governador não correspondia a verdade que "aquella ilha, tarde ou nunca há de receber illustração, ou luzes d'outro fóco luminoso que venha a haver na Provincia; mas que hade sempre brilhar por si, civilisar-se, illustrar-se - quando o não faça ás outras". Por outro lado, rebate os argumentos, segundo o qual a construção de uma povoação e a edificação de edifícios públicos necessários para o governo geral acabaria com a falta de instrução de sua população. Segundo este, a instalação do governo no interior da ilha não a tornaria mais 
ilustrada ou civilizada, uma vez que "o resto da Provincia vale mais do que a Ilha de Santiago". Além disso, esbarraria na resistência das famílias em enviar os seus filhos para a referida ilha, tendo em vista a intempérie do clima. Algumas chegaram até a reiterar que "antes quero meus filhos ignorantes do que perdel-os". Segundo esta interpretação, só haveria civilização se se permanecer o regime despótico no interior da ilha de Santiago. Podemos constatar que os deputados, apoiantes da transferência da sede do governo da vila da Praia para São vicente, criam que não era possível implantar uma civilização na ilha de Santiago, visto como ilha dos revoltosos e de ignorância. Não é por acaso que defendiam a criação de um seminário para a formação dos jovens em outras ilhas do arquipélago, como sejam: São Nicolau e São Vicente.

Para Dias, a transferência da Sede do governo geral para a ilha de São Vicente traria grandes ganhos para Cabo Verde, principalmente as receitas arrecadadas com o estabelecimento dos depósitos de carvão de pedra para abastecer os navios transatlânticos. Também possibilitava que os negociantes estabelecessem os seus depósitos de mercadorias, aproveitando a excelência do seu porto para o comércio com a Europa. Possibilitava aos funcionários do governo geral resguardar das "carneiradas", considerada como "natural e privativa da mortifera S. Thiago". Além disso, facilitaria o desenvolvimento das ilhas de Santo Antão e de São Nicolau, esquecidas pelos sucessivos governos gerais, mas importantes mercados de abastecimentos da ilha de São Vicente. Destacou ainda que se a ilha de Santiago despõe de rendimentos superiores às outras demais ilhas, devia-se principalmente ao "direito que julgam ter os habitantes de S. Thiago, para dizerem - esta é a Capital". ${ }^{22}$ Note-se que os representantes políticos de cada ilha faziam pressões para que a Coroa portuguesa sediasse o governo geral numa outra ilha. Em nenhum momento, os rendeiros do interior da ilha de Santiago viram suas reivindicações serem analisadas pelo governo geral, muito menos pela Coroa portuguesa. Aos rendeiros, sem representação política junto ao governo geral, restava subverter a ordem política vigente, como forma de protesto pela desigualdade de direitos e parcialidade das administrações locais. As elites locais procuravam unicamente em garantir os seus interesses econômicos, por meio de disputas político-partidárias que se preocupavam em destacar a dimensão cultural de cada ilha.

Por Decreto de quatro de Junho de 1835, o governador Marinho autorizou as despesas financeiras necessárias para a transferência da capital de Cabo Verde para a ilha de São Vicente, justificando ser de grande interesse do arquipélago, não só pela grandiosidade do seu porto quanto 22 AHU, Cabo Verde, Folheto - Algumas considerações sobre a fixação da Sede do Governo da Provincia, e salubridade da ilha de S. Thiago de Cabo-Verde. Cx. 54, de 1836. 
pelas motivações “moraes”. Aproveitou também para contestar os argumentos apresentados pelo ex. secretário do governo geral, David da Fonseca Pinto, segundo os quais a ilha de São Vicente não dispunha nem de fonte de água potável, mantimentos e posição geográfica privilegiada. Segundo este, a ilha de São Vicente, além das duas nascentes, denominada de Madeiral ou Madeiralsinho e Matiota, tinha trezentos habitantes. Para além disso, destacou a facilidade de abertura de poços de água potável, tendo em vista a pouca profundidade dos lenções freáticos, técnica utilizada nas ilhas do Maio e da Boa Vista. Não deixou de reiterar que as nascentes de água forneciam, diariamente, entre vinte e trinta "pipas" de água por dia aos navios baleeiros.

Com relação aos mantimentos, Dias argumentou que a ilha era "farta de mantimentos". A existência de terras incultas devia-se sobretudo, à ocupação das suas populações com outras atividades econômicas, como sejam: a criação do gado e o apanho da urzela. Além disso, a ilha de São Vicente era abastecida de gêneros alimentícios pela fértil ilha de Santo Antão. Para Marinho, apesar das ilhas do Maio, da Boa Vista e Sal serem arenosas, áridas, agrestes e sofrerem de fortes ventanias, que designavam de "brisas", era habitado por mais de sete mil indivíduos. A ilha de São Vicente tinha a vantagem de dispor de um dos melhores portos do arquipélago. Marinho critica David Fonseca, por este nunca ter visitado e inteirado das reais possibilidades da ilha de São Vicente. A ilha produzia bastante lenha, melões e melancias, milho, feijão, batatas e aboboras, além da abundância de peixes em suas encostas. O referido deputado dirigiu fortes críticas ao monopólio da terra na ilha de Santiago por parte de "coronéis", responsáveis pelo aparecimento de terras incultas. Para este, o regime de monopólio e manipulação do governo geral poderia cessar, caso a sede do governo fosse transferida para a ilha de São Vicente, onde se poderiam implantar os colégios eleitorais. Além disso, mostra que as influências políticas desses coronéis eram demasiadas, o que fracassava qualquer tentativa de mudança política, por meio de reformas.

Para atender às reivindicações dos moderados, que persistiam em sustentar que o "espirito revoltoso" e de partido dos habitantes da ilha de Santiago constituiria um grande entrava ao desenvolvimento do arquipélago, a Coroa portuguesa tomou algumas iniciativas políticas. Por Decreto, de 11 de junho de 1838, a rainha, Dona Maria II, determinou que as principais autoridades do governo geral de Cabo Verde passassem doravante a residir na ilha de São Vicente. Ainda determinou não só a construção dos edifícios necessários à administração pública, como também que a nova cidade deveria se chamar "Mindello".

Segundo o governador, brigadeiro Joaquim Pereira Marinho, Manuel Antonio Martins era 
um dos principais suspeitos da organização de um projeto de "revolução", tendo como referência a fazenda de Monte Agarro, numa das “cazas” pertencentes a este influente político. Tal suspeição foi reforçada quando o mesmo governador reiterou que "O Coronel Martins esteve na Villa da Praia desde Setembro até Dezembro (...) sem fim algum conhecido, esperando pelo desinvolvimento desta revolução, e logo que ella foi extincta, retirou-se para Boa Vista”. ${ }^{23}$ O testemunho deste é igualmente importante, ao demonstrar que o projeto de tomada da ilha de Santiago, com o assassinato de todos os brancos e proprietários, remontava os anos de 1822, com a introdução do liberalismo no arquipélago.

"Sabia que os escravos, resolvendo-se um a assassinar seu Senhor no interior, ou a qualquer proprietario, conforme era o plano que tinham, e o que podia acontecer por embriaguez, desordem ou qualquer incidente, que apparecesse, desinvolveriam imediatamente a revolução: o plano reduziase, a todos os escravos matarem a seus Senhores, a uma mesma hora, e todos os pobres matarem todos os proprietários; principiando a revolução, desinvolvia-se com a rapidez da luz; os escravos, e pobres tornavam-se Senhores do interior da Ilha de S. Thiago, seguia-se logo a guerra de côr: mata que é branco; então ser-me-hia impossivel rebater a revolução, $e$ acabaria em pouco tempo com a gente, que me fosse fiel". ${ }^{24}$

Era de tal ordem a organização em torno da organização da revolução que, segundo Marinho, existia um "Club director" em Monte Agarro, tendo por finalidade "assassinar todos os brancos e proprietários", tendo instruído os seus membros que "no espaço de dezoito legoas (...) todos os escravos deveriam assassinar seus senhores a uma mesma hora dada". Nem mesmo os proprietários detinham conhecimentos precisos dos projetos da revolução que se pretendiam fazer na ilha de Santiago - "o segredo era tal, que sendo a revolução, geralmente conhecida de todos os pretos pobres, e pretas da mesma ordem, ninguém a tinha denunciado". A revolução que se pretendia implantar na ilha de Santiago seria despoletada a partir de "uma guerra civil de côr". Para Marinho, Martins estava por detrás de todos os projetos para que fosse declarado uma revolução na ilha de Santiago. Para tanto, criou um "Club Conspirador", preparando os seus escravos para liderarem a tomada do poder político na ilha de Santiago. Também defendeu-se das acusações de Martins, reiterando que "quem a promoveu, e quem andava em procissão á testa dos proprietarios, era Martins”. A grande influência política de Martins devia-se sobretudo à grande simpatia que

23 MARINHO, Joaquim Pereira. Memória Official em resposta às accusações dirigidas A Sua Magestade contra o governador geral da provincia de Cabo Verde, o brigadeiro Joaquim Pereira Marinho. Lisboa: Typografia de A. S. Coelho, 1939, p. 82.

24 Idem, p. 81. 
granjeava junto dos demais proprietários da ilha de Santiago, sendo inclusive o seu representante junto do governo geral.

Segundo Marinho, todas as precauções políticas deveriam ser adotadas na comunicação com o interior da ilha de Santiago, pois "com os dos interior era perigoso, porque podia ser que os escravos persentissem as communicações, e logo que as persentissem, desinvolvessem a revolução". Era preciso desenvolver toda uma estratégia política para evitar a eclosão da revolução, pois do contrário "era impossivel evitar que toda a Ilha não fosse perdida". Era tamanha a influência de Martins sobre a administração de Cabo Verde, que levou Marinho a considerar que "esta província é dominada há muitos annos pela facção martinista ... tem feito na mesma provincia, em todas as epochas, tudo quanto tem querido, tem roubado, tem perseguido, tem assassinado, e tudo impunemente ... tem dominado todos os governadores". Todos que não fossem "martinista" eram perseguidos ou mesmo expulsos do arquipélago.

Para este governador geral, a ser iniciada, revolução seria um sucesso, tendo em vista que a infantaria colonial era constituída, na sua maioria, de "recrutas pretos, como os escravos, da classe dos vadios dos Campos, e de ladrões, ou ratoneiros". Destacou ainda duas dificuldades que afetava toda a estrutura militar no arquipélago. Primeiro, tendo em vista que os soldados eram amigos dos escravos que pretendiam fazer a revolução. Tal amizade advinha dos rituais em torno da cultura local - "costumados a viver juntamente, e a divertirem-se de continuo com elles nos batuques (...) e habituados a viverem em família" ${ }^{25}$. Este fala nos possibilita compreender que os habitantes da ilha de Santiago congregavam-se de tal forma em torno do batuco e da tabanca, ao ponto de considerarem-se uma grande família. Segundo, os próprios “cabos" conheciam todo o projeto de revolução a ser declarada na ilha de Santiago, preparando inclusive para a apoiar, em caso de concretização. Quando fosse declarada a revolução, os soldados desertariam, fazendo aumentar o número de escravos e rendeiros revoltosos. O grande objetivo dos atores da revolução consistia em apoderar das "propriedades, e das mulheres" e nomear como governador geral, o coronel Manoel Antonio Martins.

Por outro lado, os projetos da revolução estavam de tal sorte vincados entre os escravos e rendeiros do interior da ilha de Santiago, que levou Marinho a considerar que "Se eu deixasse então progredir a revolução, e assassinar os meus concidadãos desta Provincia, e me retirasse para onde podesse ficar mais seguro, era certamente réo (...) que não tinha forças para sugeitar os escravos

25 Idem, p. 81. 
rebeldes" $"$. O objetivo do governador visava "salvar" os interesses político-económico da Coroa portuguesa presentes nas ilhas de Cabo Verde e não ser responsabilizado pela mesma. Ao defenderse das acusações de que teria abusado do seu cargo político, Marinho pleiteou que tomou "medidas decisivas para destruir uma revolução mui perigosa", determinando a execução dos escravos que estavam à frente dos projetos de revolução. Outrossim, tais medidas políticas se justificavam, diante da ameaça de uma revolução de escravos e rendeiros do interior da ilha de Santiago.

Para o aumento das riquezas do arquipélago e do seu "povo", a Coroa deveria apostar na fundação de um novo "centro decivilização" que, segundo o governador geral, Joaquim Marinho, deveria ser sediado na ilha de São Vicente. Nesta ilha poderia ser estabelecido um depósito de todas as produções agrícolas, manufatureiras das restantes ilhas de Cabo Verde e da costa da Guiné, o que facilitaria o comércio e "sem risco algum para todos os europeos". Tal iniciativa reanimaria o comércio e a navegação com os portos da Inglaterra e da França. Segundo este, a Coroa portuguesa deveria "fazer hum centro de cevilização, para dali se espalhar as outras ilhas, onde se devem assentar todos os estabelecimentos da industria, de comercio e da navegação". Deveria também criar novas leis que aumentando as rendas do governo permitissem acabar com o déficit. O governo geral utilizava o argumento legal que o trabalho enaltecia os valores da civilização, enquanto que a indolência estava associada à selvageria. Além disso, a ilha dispunha de bons portos, sendo sua posição geográfica "a mais vantajoza pela navegação" para os navios que iam para o sul, e era capaz de receber "mais de duzentos grandes navios, e muitas especies de embarcações pequenas". Esta estratégia política visava não só impedir que os rendeiros tivessem acesso aos cargos políticos, como também educar a população nos valores da "civilização européia". ${ }^{27}$ Cabe lembrar que para Manoel Antonio Martins, os rendimentos públicos em Cabo Verde provenientes dos impostos não chegavam sequer a uma quinta parte do que seriam necessários para pagar os funcionários e suportar as despesas públicas, pressupostos fundamentais em qualquer país civilizado.

Como medidas geradoras de riquezas para todos os habitantes, o mesmo governador propôs a criação de uma companhia de acionistas "para cultivar estabelecer com a Europa, e America o commercio de azeite de purgueira, dos produtos de Dragoeiros, e anil (...) e todas as plantas preciozas do seu arquipélago", com participação de todos os grupos sociais de Cabo Verde, como sejam: morgados, rendeiros e escravos, e do próprio governo, rompendo com o modelo de

26 Idem, p. 85.

27 AHU, SEMU: Ofícios do governador Joaquim Pereira Marinho. Cx. 53, doc. 31. 
companhias fundadas para enriquecer "capitalistas já ricos". O governo deveria se esforçar para gerar riquezas suficientes para financiar os funcionários públicos, que não tinham meios financeiros senão para as suas despesas diárias. Na maioria dos casos, depois da morte dos chefes de família, estas passavam a viver em extrema miséria. A companhia possibilitava contornar tal problema sócio-econômico, gerando riquezas tanto para o governo quanto para os "cidadãos uteis" que, tendo maiores recursos financeiros poderiam melhor servir aos interesses do governo, o qual entendia que a própria Carta Constitucional estabelecia que "todos os Cidadãos se podem reunir para formarem estabelecimentos uteis", o que justificava a iniciativa de criar uma companhia, reunindo acionistas entre os funcionários públicos de Cabo Verde.

Para ultrapassar a miséria das famílias, o governador propôs que as mulheres fossem aceites como acionistas, sem direito de voto nas deliberações da companhia. Pelos estatutos, o homem só poderia ser admitido como acionista pelos "Direitos da mulher", bem como receber os lucros das ações de sua mulher, mediante uma procuração, renovável anualmente. As mulheres não poderiam também vender as suas ações, podendo deixá-las em testamento a quem quisesse desde que a sua declaração fosse feita por escrito, na presença de três a quatro pessoas de "probidade", capazes de atestar que a "acionista estava em seu perfeito juizo, e em plena liberdade". Caso contrário, reverteria para o parente mais próximo da falecida.

Os estatutos ainda previam a eleição dos corpos dirigentes dentro da companhia. As referidas eleições podem ser compreendidas como estratégias políticas para preparar os "novos cidadãos" para o exercício do direito ao voto. Dentre as tarefas do conselho de administração, cabe destacar a competência para convocar os círculos eleitorais e neles realizar eleições, as quais se procederiam com uma antecedência de dois meses do término do mandato do conselho cessante. Por sua vez, os círculos eleitorais nomeariam um representante seu para o conselho administrativo. O representante que fora nomeado por "muitos circulos" eleitorais participaria do conselho administrativo, por um mandato de dois anos. No caso de não estarem reunidas as condições para a realização das eleições, que pressupunha a apresentação da contabilidade e do balanço, qualquer acionista poderia convocar os círculos eleitorais para a eleição de um novo conselho administrativo que, por sua vez, revogaria o mandato da administração cessante. Também requisitaria os recibos que justificariam a contabilidade apresentada pela administração cessante.

Por sua vez, os estatutos previam a criação de colégios eleitorais. Estes deveriam limitar-se a analisar as questões pelas quais foram nomeados pelos círculos eleitorais. Todas as questões 
discutidas, sem prévia autorização dos círculos eleitorais, deveriam ser consideradas como "ociosidades". No decorrer das eleições, o governo nomearia um acionista como delegado no círculo eleitoral indicado pelo Conselho administrativo. Para o governador geral, o exercício dos direitos políticos para os novos cidadãos carecia de uma fase de aprendizagem e preparação para integrarem a nova ordem social liberal introduzida em Cabo Verde. Em outras palavras, para o governo geral, os habitantes não teriam capacidades políticas para se autogovernarem. Porém, a fase de aprendizagem não surtiu o efeito esperado pelo governo geral de Cabo Verde, tendo em vista que os rendeiros, além de reivindicavam a posse imediata das terras, também estavam cientes que a prática desses valores equivaleria um retorno à extrema exploração a quem estavam sujeitos.

Por outro lado, com a formação dessa junta de governo, vários magistrados, funcionários das câmaras municipais da vila da Praia e da Ribeira Grande, com destaque para Marcellino de Rezende Costa, reivindicaram, por meio do ofício de 13 de março de 1826, junto à Coroa portuguesa a elevação da vila de Santa Maria da Praia à categoria de cidade levando-se em consideração o número de habitantes. ${ }^{28}$ Também contou com participação de várias patentes do exército colonial residentes tanto na ilha de Santiago quanto na ilha do Fogo, vários capitães-mores, dentre os quais, Nicolau dos Reis Borges. Dentre os cônegos e vigários, cabe destacar: o Deão Antonio da Costa Alves; Matheus Gonçalves Varella, cônego da cidade da Ribeira Grande; padre Manoel Antonio Loppes da Crus; Frei Agostinho dos Martes, Comissário Provincial e Guardião do convento, Frei Bernardo de Fondella, vigário de São Lourenço. Além de Nicolau dos Reis Borges, tomaram parte outros influentes morgados do interior da ilha de Santiago, com sejam: Manoel carvalho Silva de Landim, enquanto coronel agregado; Domingos Ramos Monteiro, coronel reformado da cavalaria de Milicias; Francisco dos Reis da Fonseca Borges, tenente coronel. Como argumentos, os requerentes destacaram "as qualidades morais de que se revestem os habitantes, como são a nobreza; educação, dignidades Civis, e Ecleziasticas", bem como o "caracter de fidelidade" à Coroa portuguesa. Em despacho, de 24 de setembro de 1828, sob parecer do ex-governador geral, Antonio Pusich, a Secretaria do Estado dos Negócios da Marinha e Domínios Ultramarinos indeferiu o pedido dos seus habitantes. ${ }^{29}$

Segundo Pusich, a câmara da Ribeira Grande gozava de todos os "fóros" municipais, dando posse aos governadores do arquipélago. Destacou o fato dos “camaristas" serem sempre pessoas

28 AHU, Cabo Verde, Cx. 83, doc. 74, de13 de março de 1826.

29 AHU, Cabo Verde, Cx. 89-A, doc.114, de 24 de setembro de 1828. 
"principais daquella Ilha", apelidando de "Cidadãos da Cidade da Ribeira Grande". Mereceu atenção o fato que até o momento foram sempre fieis aos interesses da Coroa portuguesa. Considerou que a câmara da vila da Praia saía fora quase sempre dos limites dos seus poderes, causando distúrbios políticos. Pelo fato dos seus funcionários serem "tendeiros" 30 manipulados pelos negociantes, permitia que até os degredados se inscrevessem nos livros de matrícula. Para este político, para além de abolir a referida câmara, deveria-se criar uma nova cidade, com o nome de "Sant-iago", cujo nome representaria "o santo que d'ella he Orágo, e em cujo Dia foi descoberta".

Já por meio de um ofício $\mathrm{n}^{\circ} 72$, de 8 de abril de 1840, o então governador geral de Cabo Verde, João de Fontes Pereira de Melo (1839-1842), o “abandono da religão” em Cabo Verde, devido à miséria do clero e à ruína dos templos, constituiria um dos principais entraves " $n o$ caminho da civilização". Para tanto, tornava-se necessário que os párocos esforçassem para debelar as "preocupações absurdas, que se encontram nestes Povos", que sempre tem resistido não só às autoridades civis quanto às autoridades religiosas, que "ainda são respeitados, nas Freguezias onde existem". Por isso mesmo, o então governador geral de Cabo Verde, Joaquim Pereira Marinho, sugeriu à Coroa portuguesa, por meio de um ofício, de 5 de novembro de 1835 , a construção de um outro "centro de cevilização" na ilha de São Vicente e dali "espalhar para as outras ilhas". ${ }^{31}$

\section{Referências bibliográficas}

AMARAL, Ilídio do. Santiago de Cabo Verde: A Terra e os Homens. Lisboa: Memórias da Junta de Investigação do Ultramar, n. 18, 1964.

ANDRADE, Elisa Silva. As Ilhas de Cabo Verde: da Descoberta à Independência Nacional (1460 - 1975). Paris: Éditions L'Harmattan, 1996.

BALANDIER, Georges. “A noção de situação colonial”. Tradução de Nicolas Nyimi Campanário e revisão de Paula Montero. In: Revista dos Alunos de Antropologia da Universidade de São Paulo, n. 3, São Paulo: USP, 1993, p. 107 - 131.

BARCELLOS, Christianno José Senna. Subsídios para a História de Cabo Verde e Guiné, 5 partes. Lisboa, 1899 - 1911;

BOSI, Alfredo. Dialética da colonização. São Paulo: Cia. das Letras, 2001.

BRÁSIO, António Duarte. Monumenta Missionaria Africana, África Ocidental - 1600-1622.

30 Pessoa que arma confusão, marceeiro ou diabo.

31 AHU, SEMU, Cabo Verde, Ofícios do governador Joaquim Pereira Marinho, Cx. nº 53. 
Lisboa: Agência-Geral do Ultramar, 2a Série, v. I-V, 1968.

CARREIRA, António. Cabo Verde: Formação e Extinção de uma sociedade escravocrata (1460 1878). Porto: Imprensa portuguesa, 1972.

CHELMICKI, José Conrado Carlos de. Corografia Cabo-verdiana ou descripção geographicohistorico da Província das Ilhas de Cabo-Verde e Guiné. Lisboa: Typ. de L. C. da Cunha, 1841, t. I.

GALVÃO, Henrique e SELVAGEM, Carlos. Império Ultramarino português. Lisboa: Imprensa Nacional de Publicidade, 1951, v. I.

GUERREIRO, Padre Fernam. Relaçam Anual das Cousas que Fezeram os Padres da Companhia de Jesus nas partes da Índia Oriental, e no Brasil, Angola, Cabo Verde, nos annos de seiscentos e dous e seiscentos e três, e do processo de conversam, e christandade daquellas partes, tirada das cartas dos mesmos padres que de lá vieram. Lisboa: Per Jorge Rodriguez, 1695 (1605).

MARINHO, Joaquim Pereira. Memória Official em resposta às accusações dirigidas A Sua Magestade contra o governador geral da provincia de Cabo Verde, o brigadeiro Joaquim Pereira Marinho. Lisboa: Typografia de A. S. Coelho, 1939.

MATOS, Brigadeiro R. J. da Cunha. Compêndio histórico das possessões de Portugal na África. Rio de Janeiro: Ministério da Justiça e Negócios Interiores - Arquivo Nacional, 1963.

SAID, Edward W.. Cultura e imperialismo. Tradução Denise Bottman. São Paulo: Companhia das Letras, 1995.

VALLE, Marqués de la Fuentesanta del; RAYON, D. José Sancho; ZABÁLBURU, D. Francisco de. Coleccion de documentos inéditos para la historia de Espanã. Madrid, 1889, t. XCIV.

\section{Documentos de Época}

\section{Manuscritos}

- Arquivo Histórico Ultramarino (A.H.U.) - Cabo Verde - Conselho Ultramarino (C.U.) Correspondência recebida do Governo-Geral e demais Autoridades de Cabo Verde. Consultas, requerimentos e outro expediente do Conselho Ultramarino, Cabo Verde:

Caixas: 1, 53, 54, 66, 83, 89-A. 


\title{
Documentação
}

\section{O testamento que validou José Eduardo dos Santos na presidência de Angola em 1979}

\author{
Patrício Batsîkama \\ Historiador \\ FCS/Universidade Agostinho Neto
}

\section{Introdução}

Nas minhas andanças em Luanda e outras sedes provinciais de Angola tenho notado que a maior parte da juventude desconhece a participação de José Eduardo dos Santos na luta de libertação de Angola. O apelo dos kotas segundo o qual o atual presidente "sacrificou a sua juventude" não é bem percebido pela juventude: entrevistei, em sete cidades diferentes ${ }^{1}$, cerca de 312 jovens entre 18 e $23 \operatorname{anos}^{2}$, dos quais $238^{3}$ acham que seria apenas falácia dos kotas, pois somente a palavra deles não bastaria. A ruptura kotas/kandengues pareceu-me enorme, pela falta de transmissão da experiência [socialização]. Isso é um problema sério para qualquer sociedade, e Platão já prescreveu isso na sua obra República.

De forma breve, apresento o quadro da juventude entrevistada por mim.

\section{Províncias percorridas}

1 As cidades são: Luanda: 198; Uige: 12; Mbânz’a Kôngo: 12; Malange: 11; Lubângu: 29; Benguela: 31 ; Ondjiva: 19. Fiquemos questão de escolher apenas os estudantes entre $10^{\mathrm{a}}$ classe de Ensino Médio até $3^{\mathrm{o}}$ ano do Ensino superior. A maioria é crente: 62 católicos; 39 protestantes; 124 tokoistas. 87 restantes não pertence a nenhuma religião. As minhas entrevistas eram seletivas.

2 Esta recolha relaciona-se com o trabalho da minha Tese de Douramento.

3181 oriundos de Luanda; Uige: 6; Mbânz'a Kôngo: 9; Malange: 2; Lubângu: 17; Benguela: 11; Ondjiva: 12. As idades são entre: 18 e 23 anos; habilitações literárias: 10 classe e 2 anos de frequência universitária. 